\title{
The Use of Force, Wars of National Liberation and the Right to Self-Determination in the South Ossetian Conflict
}

\section{Introduction}

The jus ad bellum is strictly regulated under international law. Article 2(4) of the UN Charter states that: "All Members shall refrain in their international relations from the threat or use of force against the territorial integrity or political independence of any state, or in any other manner inconsistent with the Purposes of the United Nations.” ${ }^{1}$ However there are certain limited circumstances when recourse to the use of force is legal and when a state is said to have a legitimate jus ad bellum. While the two established exceptions to Art. 2(4) are accepted without question, i.e. the use of force in self-defence ${ }^{2}$ and the use of force pursuant to Security Council authorisation under Chapter $\mathrm{VII}^{3}$ of the UN Charter, ${ }^{4}$ other claims for a genuine jus ad bellum, e.g. when force is used in pursuance of the right to selfdetermination in a war of national liberation or to protect nationals abroad, are not as clear-cut. States however, are always eager to proffer justifications for their recourse to force against another state to suit their actions, in accordance with international law. This can be seen in the case of the recent conflict in South Ossetia, involving armed forces employed by both Georgia and Russia, when Russia intervened in Georgian territory in what it said was an attempt to aid the people of the Georgian region of South Ossetia. ${ }^{5}$ The jus ad bellum of this particular conflict has been commented on by leaders of both States. Georgian President Mikhail Saakashvili stated that Russian actions in Georgia were "a clear intrusion on another country's territory”, 6 while Russian President Dmitri Medvedev stated that Russian forces had been obliged to take action and intervene in South Ossetia in order to prevent genocide in the region, and that he was taking into account the "free expression of free will" of the

\footnotetext{
${ }^{1}$ Charter of the United Nations, Article 2(4). For an indepth discussion of Article 2(4) see Bruno Simma (ed.), The Charter of the United Nations; A Commentary, 2 volumes, Oxford: OUP, 2002, pp. 114 - 26.

${ }^{2}$ See Oscar Schachter, 'Self-Defense and the Rule of Law' 83 American Journal of International Law (1989), pp. 259 - 77.

${ }^{3}$ See Bruno Simma (ed.), The Charter of the United Nations; A Commentary, 2 volumes, Oxford: OUP, 2002, p. 702:

${ }^{4}$ In relation to the United Nations and the jus ad bellum see, N.D. White, The United Nations System: Toward International Justice (Boulder, Colorado: Lynne Rienner, 2002), Leland M. Goodrich, Edward Hambro and Anne Patricia Simons, Charter of the United Nations; Commentary and Documents, 3rd and revised ed. (New York \& London: Columbia University Press, 1969)

${ }^{5}$ See for example 'Russian Tanks Enter South Ossetia', BBC News, Friday $8^{\text {th }}$ August 2008, available at $<$ http://news.bbc.co.uk/2/hi/europe/7548715.stm $>$ (last accessed $7^{\text {th }}$ January 2009)

6 'Russian Tanks Enter South Ossetia', BBC News, Friday $8^{\text {th }}$ August 2008, available at

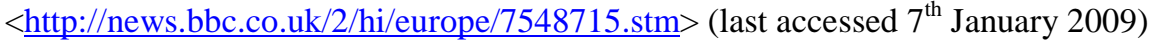


South Ossetian population, ${ }^{7}$ thus claiming that Russia had a legitimate jus ad bellum. This article will first look at the circumstances surrounding the South Ossetian conflict, and then examine the jus ad bellum regarding wars of national liberation and aggression. The concept of intervention to protect nationals abroad will also be briefly discussed. These legal paradigms will then be applied to the events of August 2008 in the region of South Ossetia to analyse the legality of the use of force in this conflict.

\section{Historical Overview of South Ossetia}

Historically, the Ossetians are of Iranian origin, and are viewed by Georgians as a non-native group living in its territory. ${ }^{8}$ Ossetia is divided into two regions - North Ossetia and South Ossetia. North Ossetia is currently an autonomous republic in the Russian Federation and previously enjoyed a similar status within the Russian Soviet Federative Socialist Republic. South Ossetia, a region within the state of Georgia, had been granted a lower status of autonomous oblast (region) within the Georgian Soviet Socialist Republic. This status was lost when Georgia became independent. As they are now situated in two different states, an international border presently divides North and South Ossetia, and the common 'nationality' link created by the Soviet Union has been erased. When Georgia was a part of the Russian Empire and subsequently the Soviet Union, the connection between North and South Ossetia was obviously very strong. However, a strong connection still exists between North and South Ossetia and indeed it is argued that currently "there is no concept of a separate South Ossetian nation and no desire to develop one. What is seen to exist is one Ossetian nation that is divided into two separate political units.” 9 Although North Ossetia is a predominantly Muslim region and South Ossetia is mainly Christian, both regions have many traditional cultural practices in common and these practices "are 'national rather than religious' in character."10

South Ossetia was part of the Russian Empire (as part of Georgia) since 1801. Following the collapse of the empire during the short-lived First Georgian Republic (1918-1921), there were a number of uprisings in South Ossetia and it adopted a declaration of independence from Georgia in 1920. The

\footnotetext{
7 'Russia Recognizes Georgian Rebels' BBC News, Tuesday, $26^{\text {th }}$ August 2008, available at $<$ http://news.bbc.co.uk/2/hi/europe/7582181.stm> (last accessed 30 ${ }^{\text {th }}$ October 2008)

8 Shireen T. Hunter, 'Borders, Conflict, and Security in the Caucasus: The Legacy of the Past', SAIS Review, Volume XXVI, Number. , (2006), p. 119.

${ }^{9}$ Pål Kolstø and Helge Blakkisrud, 'Living with Non-recognition: State- and Nation-building in South Caucasian, Quasistates', Europe-Asia Studies, Volume 60, Number 3, (2008), p. 503.

${ }^{10}$ Bogdan Szajkowski, Encyclopaedia of Conflict, disputes and flashpoints in Eastern Europe, Russia and the Successor States, Longman Current Affairs Harlow, 1993, p. 254 - quoting the work of Jane Ormond.
} 
First Georgian Republic’s Menshevik government faced many problems, including war (with Armenia and White Russian forces), economic chaos and hyperinflation. ${ }^{11}$ The Mensheviks turned to Georgian nationalism as they tried to bolster support for the state. This led to minorities, including Ossetians, feeling isolated within the state, and Georgians began to regard them as a potential fifth column which could collaborate with forces outside of Georgia to undermine the Georgian government. ${ }^{12}$ Following the defeat of the Mensheviks, the incorporation of Georgia into the Soviet Union in 1921 was followed by the establishment of an autonomous oblast of South Ossetia within the Georgian Soviet Socialist Republic. ${ }^{13}$ Unhappy with the division of Ossetia into two units in separate Soviet republics, through the 1920s and 1930s North and South Ossetian leaders sought a united Ossetia within the Soviet Union and petitioned the Soviet Union leadership for this. However their request was denied. ${ }^{14}$

Tensions were sparked again in the years leading up to the break-up of the Soviet Union, as South Ossetia failed in its attempts to have its status upgraded from that of an autonomous oblast to an autonomous republic. Such a status would have given the area greater autonomy over issues such as language and cultural policy. In 1989 the South Ossetian Soviet requested that the region be made an autonomous republic but the Georgian authorities refused to grant this. A march on Tskhinvali by Georgians in November of that year to demonstrate Georgian control of the region ended in violence. ${ }^{15}$ In the summer of 1990 regional parties were banned from Georgian elections, effectively prohibiting any South Ossetian party from participating. In response, in September South Ossetia declared full sovereignty within the Soviet Union. Georgia in turn abolished South Ossetia's autonomous oblast status completely. ${ }^{16}$ The Soviet Union did not accept South Ossetia's declaration of sovereignty or Georgia's abolition of South Ossetia's autonomous status. ${ }^{17}$ In 1989 two-thirds of the population of South Ossetia was ethnic Ossetian, ${ }^{18}$ and the main catalyst for conflict was the publication of articles in the Georgian media stating that the government was considering making Georgian the only official state language, and the subsequent declaration to that effect following Georgia's independence in 1991

\footnotetext{
${ }^{11}$ Svante E. Cornell, Small Nations and Great Powers: A study of Ethnopolitical Conflict in the Caucasus, (London: Curzon Caucasus World, 2001), p. 148.

${ }^{12}$ Ibid

${ }^{13}$ Antje Herrberg (editor), Conflict Resolution in Georgia: A synthesis analysis with a legal perspective, Crisis Management Initiative, Helsinki (2006), pp. 10 - 11.

${ }^{14}$ Shireen T. Hunter, 'Borders, Conflict, and Security in the Caucasus: The Legacy of the Past', SAIS Review, Volume XXVI, Number 1, (2006), p. 119.

${ }^{15}$ Georgia: Avoiding War in South Ossetia, International Crisis Group report 159, Brussels/Tbilisi, 2004. p. 3.

${ }^{16}$ Georgia: Avoiding War in South Ossetia, International Crisis Group report 159, Brussels/Tbilisi, 2004. p. 3.

${ }^{17}$ Antje Herrberg (editor), Conflict Resolution in Georgia: A synthesis analysis with a legal perspective, Crisis Management Initiative, Helsinki (2006), p. 11.

${ }^{18}$ Charles King, 'The Benefits of Ethnic War: Understanding Eurasia’s Unrecognized States', World Politics, Volume 53, (July 2001), p. 534.
} 
- when at the time only $14 \%$ of South Ossetians could function in Georgian. ${ }^{19}$ Cornell states that there was a total lack of will to compromise on both sides. Georgians regarded Ossetians as immigrants and a tool of Russian attempts to block Georgia's moves toward independence. Ossetians and other minorities were reacting against growing Georgian nationalism and chauvinism and attempts at Georgianization and Christianization of Georgia. ${ }^{20}$ The first Georgian President, Zviad Gamsakhurdia, suggested publicly that South Ossetians should leave Georgia and return to their 'real' homeland of North Ossetia. ${ }^{21}$ A 1993 survey illustrated that three of every four Georgians held a negative view of South Ossetians, and two-thirds rejected any compromise that would give South Ossetia significant autonomy while remaining in Georgia. ${ }^{22}$

\section{The Beginning of Violence in South Ossetia}

Clashes between South Ossetian and Georgian forces first occurred in 1989, and the situation deteriorated further in 1990 with Georgia's declaration of independence, with no internal boundaries (thereby abolishing the autonomous oblast status of South Ossetia). ${ }^{23}$ A year of armed conflict followed and led to Russia and Georgia signing the Sochi Agreement in 1992, which facilitated the setting up of a Joint Control Commission (JCC) in the region. The JCC is composed of representatives from Georgia, Russia, North and South Ossetia and the OSCE and works on security matters, economic rehabilitation and the return of displaced people. It also oversees the work of the Joint Peacekeeping Forces (JPK), comprised of Georgian, Russian and South Ossetian units. ${ }^{24}$ The Sochi Agreement and its provisions did not lead to a settlement of the situation, but rather the region entered a 'frozen' conflict phase, similar to others in the former Soviet Union (in Abkhazia, Nagorno-Karabakh and Transdniester), in that, while violence ended, no lasting peace was achieved. ${ }^{25}$ South Ossetia began to operate as a de facto state, outside of the control of Georgia despite being a part of Georgian territory. The coming to power of Georgian President Saakashvili marked a major change in relations between

\footnotetext{
${ }^{19}$ Shireen T. Hunter, 'Borders, Conflict, and Security in the Caucasus: The Legacy of the Past', SAIS Review, Volume XXVI, Number 1, (2006), p. 120.

${ }^{20}$ Svante E. Cornell, Small Nations and Great Powers: A study of Ethnopolitical Conflict in the Caucasus, (London: Curzon Caucasus World, 2001), p. 165.

${ }^{21}$ Bogdan Szajkowski, Encyclopaedia of Conflict, disputes and flashpoints in Eastern Europe, Russia and the Successor States, (Harlow: Longman Current Affairs, 1993), p. 245.

${ }^{22}$ Darrell Slider, 'Democratization in Georgia', in Karen Dawisha and Bruce Parrott (eds), Cleavage and Change in Central Asia and the Caucasus, (Cambridge: Cambridge University Press, 1997) p. 173.

${ }^{23}$ Svante E. Cornell, Small Nations and Great Powers: A study of Ethnopolitical Conflict in the Caucasus, (London: Curzon Caucasus World, 2001), pp. $164-166$.

${ }^{24}$ Antje Herrberg (editor), Conflict Resolution in Georgia: A synthesis analysis with a legal perspective, Crisis Management Initiative, Helsinki (2006), pp. 11-12.

${ }^{25}$ Information on these conflict situations is available on the International Crisis Group website at http://www.crisisgroup.org/home/index.cfm?id=1162\&l=1
} 
Georgia and the area of South Ossetia. Tensions had been low in the region for many years, especially in comparison with other frozen conflicts such as Abkhazia and Nagorno-Karabakh. However, there were attempts by the Saakashvili government to regain control of the region, including the closing of local markets that had facilitated cross-border trading. From being the most tranquil of the frozen

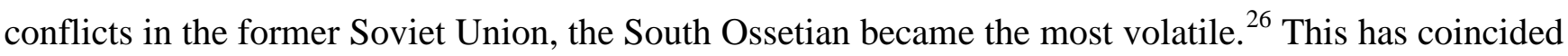
with a general deterioration of relations between Russia and Georgia. In 2005 North and South Ossetia released an agreement stating their wish for unification. ${ }^{27}$

\section{A Return to Conflict - August 2008}

Since Saakashvili's coming to power in 2004, and his attempts to regain full control of South Ossetia, tensions have risen gradually. In April Russia moved to formalize its relations with both South Ossetia and Abkhazia as President Putin signed a decree instructing the government to open political, economic and social relations with the regions. ${ }^{28}$ During April and May tensions escalated in Abkhazia, with a Georgian unmanned aerial vehicle being shot down over Abkhazian territory. In June clashes between South Ossetian and Georgian forces around Tskhinvali led to one person being killed. ${ }^{29}$ There were a small number of fatalities again in early July with an explosion killing a South Ossetian police chief and shelling of Tskhinvali. Georgian police were also injured in an attack. On July $8^{\text {th }}$ there was an incursion by Russian forces into Georgian airspace above South Ossetia, and on July $15^{\text {th }}$ the Russian armed forces commenced Operation Kavkaz-2008, engaging 8,000 troops in training exercises in close proximity to the Georgian border. The most serious clashes occurred on August $1^{\text {st }}$ and $2^{\text {nd }}$, with further attacks on Georgian police and shelling of Tskhinvali. South Ossetia claimed that 6 people, including one North Ossetian peacekeeper, were killed and 15 others injured.

It was against the background of this escalation in violence that Georgian forces then launched a comprehensive air and ground assault on the region on August $8^{\text {th }}$ and eventually captured Tskhinvali. $^{30}$ The Georgian military described its activities during this time as an attempt to restore

\footnotetext{
${ }^{26}$ Pål Kolstø and Helge Blakkisrud, 'Living with Non-recognition: State- and Nation-building in South-Caucasian Quasi states’, Europe-Asia Studies, Volume 60, Number 3, (2008), pp. 483 - 509, p. 492.

${ }^{27}$ Christopher Waters, 'Law in Places that don't exist', 34 Denv. J. Int'l L. \& Policy, Volume 34, (2006), p. 405.

${ }^{28}$ Svante E. Cornell, Johanna Popjanevski and Niklas Nillson, Russia's War in Georgia: Causes and Implications for Georgia and the World, Policy Paper, Central Asia Caucasus Institute Silk Road Studies Programme, 2008 , p. 8.

${ }^{29}$ Cornell, Popjanevski and Nillson, pps. 9-10. See letter from the Permanent Representative of Georgia to the United Nations addressed to the Secretary-General and the President of the Security Council, dated $8^{\text {th }}$ August, 2008, A/62/924 S/2008/535.

${ }^{30}$ See http://news.bbc.co.uk/2/hi/europe/country_profiles/3797729.stm, (last accessed $9^{\text {th }}$ November 2008)
} 
'constitutional order' in South Ossetia. ${ }^{31}$ Russian forces immediately responded, by sending troops into South Ossetia, crossing from the Russian Federation territory of North Ossetia, and bombing Georgian targets, claiming that it was protecting its nationals - both Russian citizens living in South Ossetia, and Russian peacekeeping forces stationed there. In the following days Russian forces sank Georgian naval vessels and destroyed a vital railway bridge linking eastern and western Georgia. ${ }^{32}$ The logistics of the Russian response to the Georgian attack on Tskhinvali included 300 combat aircraft and a blockade of the Georgian coast by the Russian Black Sea fleet. Russian troops entering undisputed Georgian territory and the deployment of 9,000 troops to Abkhazia to repel a planned Georgian assault on that region. ${ }^{33}$ Serious fighting lasted for approximately four days. Russian forces succeeded in pushing Georgian forces out of the area and proceeded to occupy areas of Georgia. A ceasefire was brought about with the help of French and U.S. intervention and a ceasefire agreement was signed on August $15^{\text {th }}$ and $16^{\text {th }}$, though fighting did not cease immediately. Russia then recognised the independence of South Ossetia, ${ }^{34}$ thus ex post facto attempting to justify its use of force as a measure to aid the South Ossetian people attain their right to self-determination.

The Russian Prime Minister Vladimir Putin had also claimed that genocide had been committed by Georgia in South Ossetia and the Russian side referred to 1,500 to 2,000 fatalities from the Georgian offensive, thus perhaps implying that Russia had a responsibility to protect the South Ossetian people. Claims were also made that Georgia committed war crimes and employed ethnic cleansing in the conflict. One BBC report claims to have found evidence that apartment blocks where civilians were taking refuge were targeted in the Georgian attacks, and that Georgia had participated in the indiscriminate bombing of residential areas and deliberate killing of civilians. ${ }^{35}$ This report also refers to Human Rights Watch information which gave a figure of 300-400 civilian fatalities, described by Human Rights Watch as a "useful starting point”. This figure would represent more than $1 \%$ of the population of Tskhinvali. ${ }^{36}$ However, another report confirms 133 fatalities. $^{37}$

It appears, not unsurprisingly, that there have been attempts on both sides to control the flow of

\footnotetext{
31 'Russia Vs Georgia: The Fallout’, Europe Report No. 195, International Crisis Group, August 2008 , p. 1.

32 Ibid, p.3.

${ }^{33}$ Roy Allison, 'Russia resurgent? Moscow’s Campaign to "coerce Georgia to peace"', International Affairs, Volume 84, Number 6, 2008, p. 1157.

${ }^{34}$ See http://news.bbc.co.uk/2/hi/europe/country_profiles/3797729.stm, (last accessed $9^{\text {th }}$ November 2008)

35 Tim Whewell, 'Georgia accused of targeting civilians', BBC News, http://news.bbc.co.uk/2/hi/in_depth/7692751.stm (last accessed 7th January 2009)

36 Ibid.

37 'Russia Vs Georgia: The Fallout', Europe Report No. 195, International Crisis Group, August 2008, p. 3
} 
information relating to the conflict. Georgia, with a western-leaning English speaking president, seems to have done a better job of this but the fuller picture which is gradually emerging through independent investigations and reports suggests that both Russia and Georgia have behaved in a manner which is incompatible with international norms. A clear-cut distinction between two parties which we traditionally may categorise as criminal and victim is not possible in this situation.

\section{The International Legal Framework}

Details of the hostilities in August 2008 continue to emerge, and there exists a continuing dispute between the two sides as to who bears responsibility for the conflict. It is accepted by most commentators that Georgian attacks in South Ossetia preceded the Russian offensive. ${ }^{38}$ However, Russia has tried to legitimise its use of force under international law by stating that it was aiding the South Ossetian people in achieving their right to self-determination and attempting to protect nationals abroad as both of these grounds have found in a place in jus ad bellum discourse in recent times.

\section{The Status of the Conflict as a War of National Liberation}

There are a number of legal issues in relation to the jus ad bellum to be considered in the present conflict. One of the major issues is the possible classification of the conflict as a war of national liberation, as Russia claimed that it intervened in the region to aid the South Ossetian people to attain their right to self-determination. The right of a people to self-determination is enshrined in the UN Charter in Art. 1 and in Art. 55, ${ }^{39}$ as well as in common Art. 1 of the International Covenant of Civil and Political Rights and the International Covenant of Social, Economic and Cultural Rights of $1966{ }^{40}$ Art. 1 of the UN Charter sets forth the purposes of the organisation, one of which is:

[t]o develop friendly relations among nations based on respect for the principle of equal rights and self-determination of peoples, and to take other appropriate measures to strengthen universal peace.

Article 55 states:

With a view to the creation of conditions of stability and well-being which are necessary for peaceful and friendly relations among nations based on respect for the principle of equal rights and self-determination of peoples, the United Nations shall promote:

\footnotetext{
38 'Russia Vs Georgia: The Fallout', Europe Report No. 195, International Crisis Group, August 2008, p. 1. Svante E. Cornell, Johanna Popjanevski and Niklas Nillson, Russia's War in Georgia: Causes and Implications for Georgia and the World, Policy Paper, Central Asia Caucasus Institute Silk Road Studies Programme, 2008, p. 14

${ }^{39}$ In relation to the right to self-determination as enshrined in the UN Charter, see Bruno Simma (ed.), The Charter of the United Nations. A Commentary, 2 volumes, Oxford: OUP, 2002, pp. 48 - 63. Wars of national liberation are dealt with pp 61 - 2.

${ }^{40}$ Adopted and opened for signature, ratification and accession by General Assembly Resolution 2200A (XXI), 1966.
} 
a. higher standards of living, full employment, and conditions of economic and social progress and development;

b. solutions of international economic, social, health, and related problems; and international cultural and educational co-operation; and

c. universal respect for, and observance of, human rights and fundamental freedoms for all without distinction as to race, sex, language, or religion.

Unfortunately, the right to self-determination has rarely been achieved without recourse to the use of force, in the form of a war of national liberation. Ronzitti defines a war of national liberation as an “armed struggle waged by a people through its liberation movement against the established government to reach self-determination." 41 The understanding of such as conflict is also clarified in Additional Protocol 1 to the Geneva Conventions in Art. 1(4) as:

armed conflicts in which peoples are fighting against colonial domination and alien occupation and against racist regimes in the exercise of their right of self-determination, as enshrined in the Charter of the United Nations and the Declaration on Principles of International Law concerning Friendly Relations and Co-operation among States in accordance with the Charter of the United Nations. ${ }^{42}$

The jus ad bellum in relation to wars of national liberation is quite complex and at times vague. The first issue that must be addressed when seeking to examine the status of the conflict as a war of national liberation, is if a claim of a people to self-determination can be made. However, even this is not without its difficulties, as was pointed out by Sir Ivor Jennings in 1956:

Nearly forty years ago, a Professor of Political Science, who was also President of the United States, President Wilson, enunciated a doctrine which was ridiculous, but which was widely accepted as a sensible proposition, the doctrine of self-determination. On the surface, it seemed reasonable: let the people decide. It was in fact ridiculous, because the people cannot decide until someone decides who are the people. ${ }^{43}$

This is an important issue in relation to any discussion on the legality of the use of force to attain selfdetermination, and indeed a salient one in identifying who, if anyone, had the right to have recourse to the use of force in the current conflict. There have been two important UN reports, by Espiell and

${ }^{41}$ N. Ronzitti, 'Resort to Force in Wars of National Liberation', in Antonio Cassese (editor) Current Problems of International Law, (Milan: Dott. A. Guiffre, 1975), p. 321.

${ }^{42}$ Protocol Additional to the Geneva Conventions of 12 August 1949, and relating to the Protection of Victims of International Armed Conflicts (Protocol 1), adopted on 8 June 1977 by the Diplomatic Conference on the Reaffirmation and Development of International Humanitarian Law applicable in Armed Conflicts. For discussion of Art 1(4) see Yves Sandoz,, Christophe Swinarski and Bruno Zimmerman (eds.), Commentary on the Additional Protocols of 8 June to the Geneva Conventions of 12 August 1949 (Geneva: Martinus Nijhoff Publishers, 1987), pp. 41 - 56.

${ }^{43}$ Sir Ivor Jennings, The Approach to Self-Government (1956), pp. 55 - 6, quoted in Anthony Whelan, 'Wilsonian Selfdetermination and the Versailles Settlement', International and Comparative Law Quarterly, Volume 43 (1994), p. 99. 
Critescu, on the issue of self-determination which set out the characteristics which attach to a 'people' entitled to the right to self-determination. These criteria have been summarised by Parker as "a history of independence or self-rule in an identifiable territory, a distinct culture and a will and capability to regain self-governance.” 44 Issues such as ethnicity, religion and language are also usually taken into account when classifying 'peoples'. 45

The claim of the existence of a jus ad bellum to obtain self-determination was never based on one central argument but rather on a number of assertions. One of the arguments used to justify the use of force by national liberation movements in pursuit of self-determination and the use of force by third states in their support was that this particular type of force was not covered by the prohibition on the use of force set out in Article 2(4) of the UN Charter. ${ }^{46}$ Also, from the beginning of the discussion on the legality of the use of force in wars of national liberation, the Just War theory was proffered as a justification. ${ }^{47}$ National liberation movements believed that they had a just cause to resort to force. Indeed, General Assembly resolutions and resolutions from other organisations have deemed the process of liberation to be "irresistible and irreversible". ${ }^{48}$ In addition, and salient in relation to the South Ossetia conflict is the argument of irredentist movements who seek to 'reunite' a national population that exists in a number of states. ${ }^{49}$

Third states, such as the Russian Federation in the present case, have often intervened in selfdetermination conflicts, both on behalf of the 'parent' state and also on behalf of the national liberation movement. While international law generally prohibits intervention, there have been a number of General Assembly resolutions, as well as some instances of state practice which relate to this issue in the context of wars of national liberation.

\footnotetext{
${ }^{44}$ Karen Parker, Understanding Self-Determination: The Basics, Presentation to First International Conference on the Right to Self-Determination, United Nations, Geneva, August 2000, available at $<$ http://www.webcom.com/hrin/parker/selfdet.html>, last accessed $9^{\text {th }}$ November 2008. These United Nations reports are: Gros Espiell, 'The Right to Self-Determination', supra note 4, and A. Critescu, 'The Rights to Self-Determination', U.N. Doc. E/CN.4/Sub.2/404/Rev.1, U.N. Sales No. E.80.XIV.3 (1980).

${ }^{45}$ See Francesco Capotorti's study entitled 'Study of the Rights of Persons belonging to Ethnic, Religious and Linguistic Minorities', E/CN.4/Sub.21384 and Add.1-7. In relation to the link between the right to self-determination and minorities, see Joshua Castellino, International Law and Self-Determination, (The Hague: Martinus Nijhoff, 2000), Chapter 2.

${ }^{46}$ See Georges Abi-Saab, 'Wars of National Liberation in the Geneva Conventions and Protocols', Recueil des Cours, Volume 165 (1979-IV), pp. 353 - 445, pp. 371 - 2.

${ }^{47}$ See James Turner Johnson, Just War Tradition and the Restraint of War (Princeton, New Jersey: Princeton University Press, 1981)

${ }^{48}$ General Assembly Declaration on Granting Independence to Colonial Countries and Peoples, General Assembly Resolution 1514 (XV), 1960, Preamble.

${ }^{49}$ See Chimène I. Keitner, The Paradoxes of Nationalism, (New York: Suny Press, 2007), p. 2.
} 
General Assembly Resolution 2131 (XX) states: "No States shall organize, assist, foment, finance, incite or tolerate subversive, terrorist or armed activities directed towards the violent overthrow of the regime of another State." 50 The Declaration on Friendly Relations, adopted by the General Assembly, also addresses this issue and again prohibits states from "organizing, instigating, assisting or participating in acts of civil strife or terrorist acts within another State....". ${ }^{1}$ Article 3(g) of the UN General Assembly's Definition of Aggression includes among its list of acts of aggression ${ }^{52}$ the $^{2}$ “...sending by or on behalf of a state of armed bands, groups, irregulars or mercenaries which carry out the acts of armed force against another State or its substantial involvement therein.”53 Obviously, standing alone, this provision would have implications for national liberation movements that could perhaps fit under the rubric of "armed bands, groups, irregulars or mercenaries” which could be seen to be engaging in acts of aggression. However, this provision is qualified by Article 7 of the Definition of Aggression, which states:

Nothing in this Definition, and in particular Article 3, could in any way prejudice the right of self-determination, freedom and independence, as derived from the Charter, of peoples forcibly deprived of that right and referred to in the Declaration on Principles of International Law Concerning Friendly Relations and Co-operation among States in accordance with the Charter of the United Nations, particularly peoples under colonial and racist regimes or other forms of alien domination; nor the right of those peoples to struggle to that end to seek and receive support in accordance with the principles of the Charter and in conformity with the above mentioned Declaration. $^{54}$

While acts committed by groups fighting for "self-determination, freedom and independence" are exempt from Article 3(g) and are therefore not acts of aggression, this provision does not go so far as to legalise the use of force by national liberation movements or on behalf of such movements by third States, as the type of 'struggle' authorised by Article 7 is not defined or clarified. Of relevance to the current case however, is that both the Declaration on Friendly Relations and the Definition of Aggression provide that people in pursuit of the exercise of their right to self-determination are entitled "to seek and to receive support" in accordance with the purposes and principles of the Charter. This implies that a third state could legally intervene on behalf of and in support of a national liberation movement although it is unclear if "support" in this context includes the use of force. ${ }^{55}$

\footnotetext{
${ }^{50}$ General Assembly Resolution 2131 (XX). 1965.

${ }^{51}$ General Assembly Resolution 2625 (XXV),1970.

${ }^{52}$ In relation to the understanding of the concept of aggression as set out in the UN Charter see, Bruno Simma (ed.) The Charter of the United Nations. A Commentary, 2 volumes, Oxford: OUP, 2002, pp. 717 - 28.

${ }^{53}$ General Assembly Resolution 3314 (XXIX), 1974.

54 Ibid.

${ }^{55}$ General Assembly Resolution 2625 (XXV),1970 and Definition of Aggression, General Assembly Resolution (XXIX), 1974, Article 7.
} 
In 1981, the Declaration on the Inadmissibility of Intervention, which affirmed the right and duty of states to support self-determination, including the right of people seeking self-determination to wage both political and armed struggle, was adopted by the General Assembly. ${ }^{56}$ This Declaration enumerates a number of rights and duties in relation to the principle of non-intervention in the internal and external affairs of states. Among these rights and duties are:

[t]he right and duty of States fully to support the right to self-determination, freedom and independence of peoples under colonial domination, foreign occupation or racist regimes, as well as the right of these people to wage both political and armed struggle to that end, in accordance with the purposes and principles of the Charter of the United Nations. ${ }^{57}$

In addition, the annual UN General Assembly resolution on the Importance of the Universal Realization of the Right of Peoples for the Effective Guarantee and Observance of Human Rights actually affirmed support for “armed struggle” between 1973 and 1991, 58 although between 1991 and 1994, the General Assembly resolutions changed in tone and affirmed support for struggle "by all available means". However, the status of the current conflict as a war of national liberation has not been debated by UN organs. $^{59}$

\section{The Right to Protect Nationals Abroad ${ }^{60}$}

Approximately 80\% of South Ossetians holding Russian citizenship. The granting of Russian passports to South Ossetians and statements by the Russian government that it will take action to protect its nationals in South Ossetia has been the source of controversy. ${ }^{61}$ While, according to Shaw, the right of

\footnotetext{
${ }^{56}$ General Assembly Resolution 36/103, 1981 (120:22:6).

${ }^{57}$ Part III (b).

${ }^{58}$ The General Assembly reaffirmed 'the legitimacy of the peoples' struggle for liberation from colonial and foreign domination and alien subjugation by all means available, including armed struggle.' - General Assembly Resolution 3070 (XXVIII), 1973, paragraph 2. From 1973 until 1990 similar language, endorsing the use of armed struggle by national liberation movements, was used in General Assembly resolutions - see Resolutions 3382 (XXX), 1975; A/RES/31/34 1976; A/RES/32/14, 1977; A/RES/33/24, 1989; A/RES/34/44, 1979; A/RES/35/35, 1980; A/RES/36/9, 1981; A/RES/37/43, 1982; A/RES/38/17, 1983; A/RES/39/17, 1984; A/RES/40/25, 1985; A/RES/41/101, 1986; A/RES/42/95, 1987; A/RES/43/106, 1988; A/RES/44/79, 1989, A/RES/45/130, 1990.

${ }^{59}$ Predictably, because of the involvement of Russia, a veto-holding member of the Security Council, in the conflict, the activities in South Ossetia have been largely ignored by the Security Council. There were two Security Council Resolutions regarding Georgia in 2008, Res. 1839, 9 Oct 2008 and Res. 1808, 15 April 2008 but neither comment on the status or categorisation of the conflict. More information on the conflict can be found in reports of the Secretary-General - see S/2008/480 23 July 08 and S/2008/631 3 Oct 2008.

${ }^{60}$ For a discussion of this issue, see Tom Ruys, 'The 'Protection of Nationals' Doctrine Revisited, Journal of Conflict and Security Law, Volume 13(2) (2008), pp. 233 - 71.

${ }^{61}$ See for example 'U.S. Criticizes Russian moves in South Ossetia, praises Georgia’ March $2^{\text {nd }}$, 2006, Radio Free Europe/Radio Liberty, available at < http://www.rferl.org/content/article/1066312.html > (last accessed 7th January 2009) and 'Tension defused as Georgia pulls back troops in South Ossetia', Daniel McLaughlin, The Irish Times, $21^{\text {st }}$ August
} 
a state to take action to protect its nationals abroad was seen as lawful in the nineteenth century, ${ }^{62}$ the situation is now less clear, as “of necessity the 'territorial integrity and political independence' of the target state is infringed”. ${ }^{63}$ Malanczuk argues that most states now agree that action taken to protect nationals abroad requires the consent of the state where the action will take place. ${ }^{64}$ The United States has used the concept to justify action in Grenada and Panama, though in both cases the level of threat "was such as to raise serious questions concerning the satisfaction of the requirement of proportionality." 65 Bowett states that views of the right to protect nationals abroad "depends as much on considerations of policy as on legal argument." 66 Shaw suggests that the rule should be accepted as valid "in carefully restricted situations consistent with the conditions laid down in the Caroline case."67 These conditions were "a necessity of self-defence, instant, overwhelming, leaving no choice of means and no moment for deliberation" and also that the act "justified by the necessity of self-defence, must be limited by that necessity, and kept clearly within it" ${ }^{68}$ One commentator states that "[there must be (1) an imminent threat of injury to nationals, (2) a failure or inability on the part of the territorial sovereign to protect them and (3) measures of protection strictly confined to the object of protecting them against injury" ${ }^{69}$ in order for an intervention to protect nationals abroad to be valid. The right to intervene on humanitarian grounds in general has however, been gaining in acceptance since the formulation of the responsibility to protect doctrine in $2001,{ }^{70}$ which requires states to protect their own citizens but when they cannot or they are unwilling to do so, places the responsibility to protect on the international community and allows for intervention to accommodate such protection.

\section{Applying the Legal Framework to the South Ossetian Conflict}

The Conflict as a War of National Liberation

If the South Ossetian conflict is to be seen as a war of national liberation, it is first necessary to examine the legitimacy of any claims to a right to self-determination that the people of South Ossetia

2004.

${ }^{62}$ Malcolm N. Shaw, International Law, $5^{\text {th }}$ Edition, (Cambridge: Cambridge University Press, 2003), p. 44.

${ }^{63}$ Ibid p. 1032

${ }^{64}$ Pater Malanczuk, Akehurst's Modern Introduction to International Law, $7^{\text {th }}$ Revised Edition, (UK: Routledge, 1997), p. 315

${ }^{65}$ Malcolm N. Shaw, International Law, $5^{\text {th }}$ Edition, (Cambridge: Cambridge University Press, 2003), p. 1033.

${ }^{66}$ Derek W. Bowett, 'The Use of Force for the Protection of Nationals Abroad', in Antonio Cassese (editor), Current Legal Regulation of the Use of Force, (Dordrecht : Martinus Nijhoff, 1986), p. 39.

${ }^{67}$ Malcolm N. Shaw, International Law, $5^{\text {th }}$ Edition, (Cambridge: Cambridge University Press, 2003), p. 1034.

${ }^{68}$ Ibid, p. 1024.

${ }^{69}$ Sir Humphry Waldock, quoted in Yoram Dinstein, War, Aggression and Self-Defence, $4^{\text {th }}$ Edition, (Cambridge: Cambridge University Press, 2005), p. 231.

${ }^{70}$ The Responsibility to Protect Doctrine is to be found in a Report of the International Commission on Intervention and State Sovereignty and is available at http://www.iciss.ca/pdf/Commission-Report.pdf. 
might make. It has been argued that South Ossetians, as a distinct 'people', do have a right to selfdetermination, but this does not automatically entail a right to full independence or statehood. ${ }^{71}$ South Ossetia has a history of some degree of autonomous rule as an oblast in the Georgian Soviet Socialist Republic, and also a history of struggling for self-determination, particularly in the period from 1918 to 1921 and from 1989 onwards, both at times when close ties with Russia were threatened. South Ossetian identity is closely linked with that of North Ossetia. The official policy of the South Ossetian de facto government is to seek integration into the Russian Federation and reunification with North Ossetia within the Russian Federation. ${ }^{72}$

Looking again at Parker's summary of criteria for self determination - "a history of independence or self-rule in an identifiable territory, a distinct culture and a will and capability to regain selfgovernance" $^{73}$ - it is clear that there is a history of self-rule in an identifiable territory, and events of recent years have shown a will for self-governance. Ossetians have a culture which is seen as distinct. As already mentioned, they are of Iranian origin, speak a different language, and are seen by Georgians as non-native settlers. Although South Ossetia's capacity for self-governance is heavily reliant on its close relations with the Russian Federation, ${ }^{74}$ self-determination could be of a form which maintains this close link, such as an autonomous Ossetian republic within the Russian Federation, as is their desire. Given that there is reluctance on the Georgian side to consider changing the status of South Ossetia, the right to self-determination, in whatever form it might take, becomes an important issue as this right is clearly being denied to a minority group in the state and this group feels threatened as a result. It must also be pointed out that South Ossetia's stance has failed to promote the possibility of a settlement of this issue.

\section{The use of force in pursuit of South Ossetia's right to self-determination}

The Declaration on Friendly Relations and the Definition of Aggression both refer to the right of people seeking self-determination "to seek and to receive support", thus perhaps implying that Russia

\footnotetext{
${ }^{71}$ Antje Herrberg (editor), Conflict Resolution in Georgia: A synthesis analysis with a legal perspective, Crisis Management Initiative, Helsinki (2006), p. 4. In relation to what the right to self-determination entails, see Bruno Simma (ed.), The Charter of the United Nations. A Commentary, 2 volumes, Oxford: OUP, 2002, pp. 58 - 9.

${ }_{72}^{72}$ Christopher Waters, 'Law in Places that don't exist', Denv. J. Int'l L. \& Policy, Volume 34, (2006), p. 411.

${ }^{73}$ Karen Parker, Understanding Self-Determination: The Basics, Presentation to First International Conference on the Right to Self-Determination, United Nations, Geneva, August 2000, available at http://www.webcom.com/hrin/parker/selfdet.html, last accessed $9^{\text {th }}$ November 2008. These United Nations reports are: Gros Espiell, 'The Right to Self-Determination', supra note 4, and A. Critescu, 'The Rights to Self-Determination', U.N. Doc. E/CN.4/Sub.2/404/Rev.1, U.N. Sales No. E.80.XIV.3 (1980).

${ }^{74}$ Pål Kolstø and Helge Blakkisrud, 'Living with Non-recognition: State- and Nation-building in South Caucasian, Quasistates', Europe-Asia Studies, Volume 60, Number 3, (2008), p. 507.
} 
could be legally justified in using force in aiding the people of South Ossetia to achieve their right to self-determination. However, both of these documents also emphasise that the right "to seek and receive support” is aimed in particular at those who have been forcibly deprived of their right to selfdetermination, and those who are under racist or colonial regimes, or other forms of alien domination. Even if it is accepted that South Ossetians constitute a people with a right to self-determination, it must also be accepted that this does not mean an automatic right to secession and self-determination can be exercised in a number of ways, including self-government and autonomy. There has been a failure on both sides to compromise on the issue of self-determination.

While relations between the Georgian authorities and South Ossetian separatists have frequently led to acts of violence being committed by both sides, this does not equate Georgia to a racist or colonial regime. Indeed if the Just War argument for the use of force in this case is followed through, oppression and/or colonial rule are key elements to it. The situation in Georgia and South Ossetia is one of a complicated shared history, with distinct ethnic groups existing on the same territory. In the protracted South Ossetian conflict both sides have been responsible for acts of violence and for failures to progress towards a lasting peace, but there does not seem to have been systematic oppression. As the UN has also rejected all irredentist claims in relation to self-determination arguments, it seems unlikely that Russia's use of force could be deemed to be justified under the legal framework concerning wars of national liberation. ${ }^{75}$

\section{The use of force by the Russian Federation as an act of aggression}

If it is held that the South Ossetian right to self-determination does not in itself constitute a right to secession, and if it is also held that South Ossetia's struggle for self-determination is not one which is being waged against a racist, colonial or alien regime, the possibility then arises that Russia's support for South Ossetian insurgents could be viewed in a different way. Article 3 of the Definition of Aggression outlines some acts which could be considered acts of aggression, including an invasion or attack by armed forces, any military occupation, bombardment, or an attack on the land, sea or air forces of another state. The actions of Russian Federation forces clearly amounted to some if not all of these actions over the course of the conflict. While Russian leaders spoke of genocide in South Ossetia, which, if it were true, might justify supporting the insurgents under the rubric of humanitarian

\footnotetext{
${ }^{75}$ In relation to irredentism and South Ossetia, see: http://www.jamestown.org/single/?no_cache=1\&tx_ttnews\%5Btt_news\%5D=33639. In relation to irredentism and the United Nations, see Thomas Franck, 'The Stealing of the Sahara', American Journal of International Law, Volume 70, (1976), pp. 694 - 721.
} 
intervention $^{76}$ or the responsibility to protect doctrine, ${ }^{77}$ no evidence was subsequently found to support the allegation of genocide. It is clear, therefore, that there is a basis for Russian actions to be deemed to constitute an act of aggression. However, Russia has also defended its activities of August 2008 under the protection of nationals abroad doctrine.

\section{The Russian Federation's Right to Protect Nationals Abroad}

At the outset of the conflict in South Ossetia, Russian President Dmitri Medvedev declared his intention to defend Russian citizens in South Ossetia. ${ }^{78}$ As already stated, approximately $80 \%$ of South Ossetians hold Russian passports. ${ }^{79}$ Bearing in mind the conditions set out above for right to protect nationals abroad, Russia's claim to such a right is weak. The seriousness of the threat to Russian citizens in South Ossetia is unclear, though it is certain that Russian claims of acts of genocide were unfounded. While the chronology of events left little time for deliberation it is clear that the actions of the Russian Federation were not limited to the necessity of self-defence. It is also clear that the principle of proportionality, which is central to any right to protect nationals abroad, has not been respected. The sinking of Georgian vessels or bombing of a railway bridge in Georgian territory outside of South Ossetia cannot easily be justified as measures which are strictly confined to the object of protecting Russian citizens in South Ossetia. Up to 20,000 Russian troops were mobilized together with 100 tanks. $^{80}$ The principle of proportionality would require that any incursion was kept to a minimum, and would cease as soon as possible. ${ }^{81}$ There were also a small number of Russian peacekeepers stationed in South Ossetia at the outbreak of the conflict. Here again the principle of proportionality is relevant. By August $9^{\text {th }}$ Georgian forces were beginning to retreat from Tskhinvali, and incursions by Russian forces into Georgian territory outside of South Ossetia were not necessary to protect these Russian peacekeepers. Furthermore, the Russian Federation's practice in recent years of offering citizenship to people living in former Soviet states and then claiming a right to protect these nationals is a significant factor which undermines any claims to such a right.

\footnotetext{
${ }^{76}$ See Edward McWhinney, The United Nations and a New World Order for a New Millennium - Self-determination, State Succession and Humanitarian Intervention (The Hague/Boston/London: Kluwer Law International, 2000),

${ }^{77}$ See the Report of the International Commission on Intervention and State Sovereignty, available at http://www.iciss.ca/report-en.asp, last accessed $9^{\text {th }}$ November 2008.

${ }^{78}$ BBC News, 'Russian Tanks Enter South Ossetia', http://news.bbc.co.uk/2/hi/europe/7548715.stm (last accessed 7th January 2009)

${ }^{79}$ Christopher Waters, 'Law in Places that don’t exist', 34 Denv. J. Int'l L. \& Policy, Volume 34, (2006) p. 405.

80 'Russia Vs Georgia; The Fallout', p. 29.

${ }^{81}$ Yoram Dinstein, War, Aggression and Self-Defence, $4^{\text {th }}$ Edition, (Cambridge: Cambridge University Press, 2005$)$, p. 232.
} 


\section{Conclusion}

Analysing the jus ad bellum in any conflict is always fraught with difficulty, as parties to a conflict will generally try to justify their use of force in some way in accordance with the international legal framework. The international legal framework on the use of force has often been stretched to accommodate and justify situations and events from different angles and perspectives. Given the vague nature of the law on the use of force in relation to wars of national liberation and the uncertainty regarding the right to protect nationals abroad doctrine, the case for the legality of the Russian Federation's use of force is not without question. At the same time, the nature of Georgia's offensive in South Ossetia also raises many questions with regard to its severity and intensity. A criminal / victim distinction satisfies our need to categorise actors into 'good' and 'bad', but the complexity of interstate relations often makes such a distinction impossible. Georgia's action in South Ossetia, and the ensuing flood of displaced peoples into the Russian Federation, does represent a genuine threat to peace and security in the region. These displaced people go to North Ossetia, which is itself involved in an ongoing conflict with Ingusheita, and the influx of people puts extra stress on the resources of an already troubled area. However, whatever the justification offered by the Russian Federation for its actions in South Ossetia in August 2008, its incursions beyond South Ossetia into other regions of Georgia must be seen as an act of aggression rather than a justifiable or appropriate response to the initial Georgian mobilisation. The main issue now for the people of South Ossetia, who experienced violence and destruction on a horrific scale in August 2008, and who had endured many difficulties as a

minority group within the state of Georgia for many years prior to this date, is finding a way to attain their right to self-determination without a return to violence. 